\title{
Optimization of sustaining swimming speed of matrinxã Brycon amazonicus: performance and adaptive aspects
}

\author{
Gustavo Arbeláez-Rojas; Gilberto Moraes* \\ UFSCar - Depto. de Genética e Evolução, C.P. 676 - 13565-905 - São Carlos, SP - Brasil. \\ *Corresponding author < gil@power.ufscar.br>
}

\begin{abstract}
Deleterious changes in metabolism, growth performance and body composition may be observed if fish are constrained to swimming continuously or intermittently at over-speeds. This study evaluates effects of four water speeds on growth, body composition and hematologic profile of juvenile matrinxã, Brycon amazonicus. Fish $(33.3 \pm 0.9 \mathrm{~g}$ and $13.44 \pm 0.1 \mathrm{~cm})$ were held for 90 days in five water speeds $(0.0$ - control, 1.0, 1.5, 2.0 and 2.5 body lengths per second - BLAt swimming speeds ranging on 1.0 and $1.5 \mathrm{BL} \mathrm{s} \mathrm{s}^{-1}$, in fish growth was $20 \%$ higher. Hemoglobin and red blood cells at $1.5 \mathrm{BL} \mathrm{s}^{-1}$ increased $24 \%$ and $18 \%$ respectively; hematocrit was $17 \%$ higher in all exercised fish; protein content of white muscle at $1.0 \mathrm{BL} \mathrm{s} \mathrm{s}^{-1}$ was $2 \%$ higher; lipid deposition in red muscle at $1.0 \mathrm{BL} \mathrm{s}^{-1}$ was $22 \%$ higher and water retention $3 \%$ lower. Crude energy levels enhanced $10 \%$ in all exercised fish; liver water retention was $6 \%$ lower at $1.0 \mathrm{BL} \mathrm{s}^{-1}$; liver lipid composition was $29 \%$ higher than control and $34 \%$ higher than $1.5 \mathrm{BL} \mathrm{s}^{-1}$; liver crude energy increased at $1.0 \mathrm{BL} \mathrm{s}{ }^{-1}$ as compared with control and $2.5 \mathrm{BL} \mathrm{s}^{-1}$. Lipid deposition in ventral muscle was $9 \%$ higher at $2.0 \mathrm{BL} \mathrm{s}{ }^{-1}$. Although high lipid deposition of matrinxã has been achieved in moderate swimming speeds, lipids may be the main fuel source to maintain the metabolic demands of exercised matrinxã. The best water flow speed for optimized growth of matrinxã ranged on 1.0 and $1.5 \mathrm{BL} \mathrm{s}^{-1}$.
\end{abstract}

Key words: body composition, exercise, fish growth, hematology, sustained swimming

\section{Otimização da velocidade de nado sustentado em matrinxã Brycon amazonicus: rendimento e aspectos adaptativos}

\begin{abstract}
RESUMO: Modificações deletérias no metabolismo, rendimento de crescimento e composição corporal podem ser observadas em peixes forçados à natação contínua ou intermitente sob velocidades excessivas. Neste trabalho, os efeitos de quatro velocidades de água no crescimento, composição corporal e perfil hematológico foram avaliados em matrinxãs juvenis, Brycon amazonicus. Os peixes $(33,3 \pm 0,9 \mathrm{~g}$ e 13,44 $\pm 0,1 \mathrm{~cm})$ foram mantidos durante 90 dias em cinco velocidades de água ( 0,0 - controle; 1,$0 ; 1,5 ; 2,0$ e 2,5 comprimentos corporais - BL por segundo). As melhores velocidades de nadado estiveram entre $1,0 \mathrm{e} 1,5 \mathrm{BL} \mathrm{s}^{-1}$, nas quais o crescimento dos peixes foi $20 \%$ maior que nas outras. A hemoglobina e as células vermelhas do sangue em $1,5 \mathrm{BL} \mathrm{s}^{-1}$ aumentaram $24 \%$ e $18 \%$ respectivamente; o hematócrito foi $17 \%$ maior em todos os peixes exercitados; o conteúdo de proteína do músculo branco em 1,0 BL s $\mathrm{s}^{-1}$ foi $2 \%$ maior; a deposição de lipídio no músculo vermelho em $1,0 \mathrm{BL} \mathrm{s}{ }^{-1}$ foi $22 \%$ maior e a retenção de água foi $3 \%$ menor. Os níveis de energia bruta aumentaram $10 \%$ em todos os peixes exercitados; a retenção de água no fígado foi $6 \%$ menor em 1,0 $\mathrm{BL} \mathrm{s}^{-1}$; a composição de lipídio no fígado foi $29 \%$ maior do que o controle e $34 \%$ maior do que a $1,5 \mathrm{BL} \mathrm{s}^{-1}$; a energia bruta no fígado aumentou em $1.0 \mathrm{BL} \mathrm{s}{ }^{-1}$ comparada com o controle e 2,5 $\mathrm{BL} \mathrm{s}^{-1}$. A deposição de lipídio no músculo ventral foi $9 \%$ maior em 2,0 $\mathrm{BL} \mathrm{s} \mathrm{s}^{-1}$. Embora alta deposição de lipídio em matrinxã tenha sido obtida em velocidades moderadas de nado, os lipídios podem ser a fonte de combustível principal para manter as exigências metabólicas de matrinxã em exercício. A melhor velocidade de nado para obter o melhor crescimento em matrinxã está entre 1,0 e 1,5 BL s .

Palavras-chave: composição corporal, exercício, crescimento, hematologia
\end{abstract}

\section{Introduction}

There is a direct relationship among fish health, nutrient assimilation, ability to respond to diet changes and body composition (Shearer, 1994; Jobling, 2001). The body composition (BC) of fingerling fish age while lipid contents increase, but proteins are a fixed fraction in fish carcass (Yogata and Oku, 2000; Rasmussen, 2001; Weatherley and Gill, 1983). Enhancement of food conversion and growth rate is fundamental in aquaculture operations. Both endogenous factors are directly related to size and body mass.
Among exogenous factors, food intake is also critical. For instance, dietary lipid composition is reflected in quality and fatty content of fillet, which is basically protein (Kiessling et al., 2005). Culture environment versus habitat, or rest state versus exercise condition are also relevant external factors (Rasmussen, 2001). Fish culture under sustained swimming may result in growth stimulation, increased protein synthesis, feeding efficiency, glycogen storing, lipid increase in liver and muscle, increased haemoglobin concentration, reduced aggressiveness (Davison and Goldspink, 1977; Johnston and Moon, 1980; Davie et al., 1986; Lay and Baldwin, 1999; 
Hackbarth and Moraes, 2006), improvement of meat quality (Bugeon et al., 2003; Bjornevik et al., 2003), changes on poly-unsaturated fatty acids profile (Kiessling et al., 2005), and reduction of size heterogeneity (Christiansen and Jobling, 1990; Davison, 1997).

Among freshwater fish with manifest farming potential, the neotropical matrinxã Brycon amazonicus, is a promising species (Gomes and Urbinati, 2005; Scorvo Filho and Marques, 1998; Arbeláez-Rojas et al., 2002; Brandão et al., 2005). Exercise improves many aspects on the species growth and development performance, such as increased protein and reduced lipids contents of fillet, as reported by Arbeláez-Rojas and Moraes (2009) and Hackbarth and Moraes (2006). Therefore, it is interesting to evaluate the relevance of exercise intensity on body composition, growth and hematological profiles of juvenile matrinxa submitted to sustained swimming.

\section{Material and Methods}

Juvenile matrinxã (Brycon amazonicus) were hauled to 2000-L fiberglass tanks in a closed loop system and fed for three weeks with a commercial diet (36\% crude protein - CP) under natural photoperiod for acclimation purposes. Next, fish were parted into uniform-sized groups $(13.44 \pm 0.1 \mathrm{~cm} ; 33.33 \pm 9.5 \mathrm{~g})$ and stocked into five, 250-L circular fibreglass tanks $(n=20)$, each animal representing one experimental unit. Fish were individually tagged with a microchip for posterior assessment of individual growth.

\section{Sustained swimming system}

Tanks had conical-shaped bottom leaning $20^{\circ}$ from the edge to a central outlet for easy cleaning, auto-disposal of organic matter and debris. Tanks were supplied by biologically filtered water under controlled temperature. Water flow was adjusted to the needed circular water speed with the aid of $3 / 4 \mathrm{HP}$ pumps, and gauged with a mechanical flow meter (General Oceanic Inc., Miami, Florida). Fish were kept out or the central region of the tanks by a PVC net column (1/3 of total tank diameter). Since the tangential speed decreases from the edge to the centre of cylindrical containers, these columns allowed fish to swim into a circular, narrow water column under constant, regular speed.

\section{Water quality}

Water parameters were checked three times a week and the average values during the trials were: temperature $27.5 \pm 0.9^{\circ} \mathrm{C}$; dissolved oxygen $5.3 \pm 0.07 \mathrm{mg} \mathrm{L}^{-1}$; pH $7.2 \pm 0.4$; ammonia $0.03 \pm 0.04 \mathrm{mg} \mathrm{L}^{-1}$, and conduc-

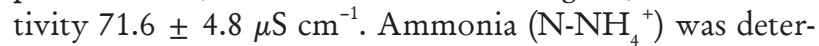
mined by colorimetric method (Gentzkow and Masen, 1942) and chemical-physical parameters by electrometric procedures $\left(\mathrm{pO}_{2}\right.$ by YSI 55 oxymeter and $\mathrm{pH}$ by Orion $710 \mathrm{pHmeter)}$. The fish were acclimated in such system for one week before trials.

\section{Experimental design}

Statistic design considered five treatments - speeds, randomly assigned to tanks - with experimental units represented by 20 tagged fish per treatment. Fish ordinarily swam counter water flow. The water speed was monitored at distinct positions and adjusted as needed each two weeks. The water speeds were 0 (control), 1.0, 1.5, 2.0 and 2.5 body-length (BL) per second. Fish were fed to satiety for 90 days with an extruded, commercial diet $(32 \% \mathrm{CP})$ under natural photoperiod (May-July). Individual biometry (length and weight) was performed every 21 days; fish were anesthetized with $40 \mathrm{mg} \mathrm{L}^{-1}$ eugenol before handling (Inoue et al., 2003).

At the end of trial, feeding was discontinued for 24h; 10 fish were randomly sampled from each tank and blood samples drawn from the caudal vein in heparinized syringe. Six fish were sampled per treatment, anaesthetized, euthanized and kept at $-20^{\circ} \mathrm{C}$ for body composition (crude protein, ether extract, crude energy, and dry matter) of white muscle (collected at the dorsal portion of the body), red muscle (collected at the lateral line of the body), ventral muscle (collected at the ventral region of the body) and liver (AOAC, 1990).

\section{Hematology}

Hematocrit (Collier, 1944), total haemoglobin (Drabkin, 1948), and red cell counting (Lima et al., 1969) were determined using the blood samples.

\section{Statistics}

Variability among treatments was detected by oneway ANOVA followed by Tukey's multiple range test (Sokal and Rohlf, 1980) $(\alpha=0.05)$. Data concerning the Uniformity Index were submitted to angular transformation before analyses. Statistic evaluation was done with Statistical Analyses System (SAS) version 8.0.

\section{Results}

\section{Growth and behavior}

The growth of matrinxa was affected by the swimming speed. No significant differences were observed on body weight of fish kept at 1.0 and $1.5 \mathrm{BL} \mathrm{s}^{-1}$. Fish encouraged to swim at $1-1.5 \mathrm{BL} \mathrm{s}{ }^{-1}$ presented enhanced body mass in comparison to other water speed conditions. The increase of the swimming speed from 1.5 to $2.5 \mathrm{BL} \mathrm{s}{ }^{-1}$ resulted in reduction of growth tending to the same performance of the non-exercised fish (Figure 1). Fish kept at $1.5 \mathrm{BL} \mathrm{s}^{-1}$ presented better size uniformity $(95.45 \%)$ while those kept $2.5 \mathrm{BL} \mathrm{s}^{-1}$ presented uneven size (Table 1). Condition factor was higher (1.0450) in fish swimming at $1.5 \mathrm{BL} \mathrm{s}^{-1}$, and the specific growth rate was higher in fish swimming at $1.0-1.5 \mathrm{BL} \mathrm{s}^{-1}(1.72)$; in this case, values were $17 \%$ higher than control group. Fish encouraged swimming at $1.0-1.5 \mathrm{BL} \mathrm{s}^{-1}$ were $20 \%$ heavier than those kept in standing waters. The most efficient feed conversion and the highest daily weight gain was observed at $1.0 \mathrm{BL} \mathrm{s}^{-1}$. 
Fish kept in flowing water systems at different speeds positioned against the water flow showing typical reofilic, schooling behavior, crowding near tank bottom. Fish surfaced usually only at feeding time during the day but dispersed across the entire water column during the night.

\section{Hematology}

Fish swimming at $1.5 \mathrm{BL} \mathrm{s}^{-1}$ presented the highest hemoglobin concentration (24\%) and the largest number

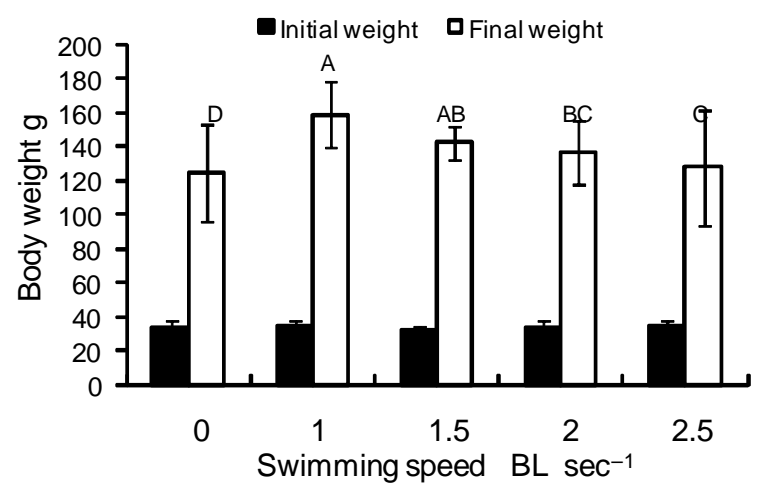

Figure 1 - Initial and final body-weight expressed as mean \pm SD of juvenile matrinxa Brycon amazonicus, submitted to sustained swimming at $0.0 ; 1.0 ; 1.5 ; 2.0$ and $2.5 \mathrm{BL} \mathrm{sec}^{-1}$. Different superscript letters mean difference among treatments $(p<0.05)$. of red blood cells (18\%). The hematocrit value increased about $17 \%$ in all exercised fish groups. No variations were detected in the other hematological parameters (Table 2).

\section{Body composition (BC)}

Protein content of white muscle of fish kept at 1.0 $\mathrm{BL} \mathrm{s} \mathrm{s}^{-1}$ was $3 \%$ higher than control or than higher water speed groups. Red muscle of fish encouraged to swimming at $1.0 \mathrm{BL} \mathrm{s}^{-1}$ stored the highest lipids contents $(42 \%)$ and the lowest water contents (3\%) compared to control group. Crude energy of red muscle was in average $10 \%$ higher in all groups of exercised fish. The liver water content was $6 \%$ lower in fish swimming at $1 \mathrm{BL} \mathrm{s}^{-1}$, in comparison to those kept at $2 \mathrm{BL} \mathrm{s}^{-1}$. In such groups, liver lipid and crude energy contents were, in average, $23 \%$ and $8 \%$ higher than other conditions, respectively. However, lipid deposition in ventral muscle was $9 \%$ higher in fish kept at $2 \mathrm{BL} \mathrm{s}^{-1}$ (Table 3).

\section{Discussion}

Because of its omnivorous alimentary habit, fast growth rate, easy adaptability to farming systems and good feed conversion rates, the Amazonian Characin matrinxa is a biological model well fitted to intensive fish farming (Gomes and Urbinati, 2005; Scorvo Filho and Marques, 1998; Brandão et al., 2005). The species'

Table 1 - Growth performance of juvenile Brycon amazonicus under sustained swimming.

\begin{tabular}{lccccc}
\hline \multirow{2}{*}{ Item } & \multicolumn{5}{c}{ Water speed } \\
\cline { 2 - 6 } & 0 & 1 & 1.5 & 2 & 2.5 \\
\hline THI $^{\mathrm{I}}(\%)$ & 71.72 & 91.00 & 95.45 & 76.20 & 68.20 \\
DWG $^{\mathrm{II}}$ & 1.0 & 1.4 & 1.2 & 1.1 & 1.0 \\
$\mathrm{~K}^{\mathrm{III}}$ & $0.9997^{\mathrm{b}}$ & $1.0097^{\mathrm{b}}$ & $1.0450^{\mathrm{a}}$ & $0.9735^{\mathrm{c}}$ & $0.9969^{\mathrm{b}}$ \\
$\mathrm{AFCE}^{\mathrm{IV}}$ & 1.33 & 1.20 & 1.50 & 2.40 & 2.30 \\
SGRV (\%) & $1.43^{\mathrm{b}}$ & $1.71^{\mathrm{a}}$ & $1.72^{\mathrm{a}}$ & $1.54^{\mathrm{ab}}$ & $1.50^{\mathrm{b}}$ \\
\hline
\end{tabular}

Fish were held for 90 days at five water speeds expressed in BL (body length) $\mathrm{s}^{-1}$. ${ }^{\mathrm{T} H \mathrm{II}}$ (treatments homogeneity index) $=\left(\mathrm{N}_{20} / \mathrm{Nt}\right)$ x 100 (Furuya et al., 1998); $\mathrm{N}_{20}=$ number of fish $20 \%$ upper the mean weight of the tank; $\mathrm{Nt}$ total number of fish. "IDWG (daily weight gain) $=\left(\right.$ final biomass - initial biomass) $/$ trial length in days. ${ }^{\mathrm{II}} \mathrm{K}$ (condition factor) $=$ total weight $\left./(\text { total length })^{\mathrm{b}} ;{ }^{\mathrm{b}}\right)=$ angular coefficient from the regression between (total weight)/(total length). ${ }^{\text {IV } A F C E ~(a p p a r e n t ~ f e e d ~ c o n v e r s i o n ~ e f f i c i e n c y) ~}=$ food consume/weight gain. VSGR (specific growth rate) $=[\ln$ final weight $-\ln$ initial weight $/$ time (days) $] \times 100$. Values are expressed as mean \pm S.D for three replications. Different superscript letters mean differences at $p<0.05$.

Table 2 - Hematological parameters ${ }^{\mathrm{I}}$ of juvenile Brycon amazonicus submitted to sustained swimming.

\begin{tabular}{lccccc}
\hline Haematological & \multicolumn{5}{c}{ Water speed } \\
\cline { 2 - 6 } Parameter & 0.0 & 1.0 & 1.5 & 2.0 & 2.5 \\
\hline $\mathrm{Hb} \mathrm{g} \%$ & $9.6 \pm 0.7^{\mathrm{b}}$ & $10.9 \pm 3.5^{\mathrm{ab}}$ & $12.7 \pm 3.4^{\mathrm{a}}$ & $10.6 \pm 1.6^{\mathrm{ab}}$ & $10.4 \pm 1.6^{\mathrm{ab}}$ \\
$\mathrm{RBC}\left(106 / \mathrm{mm}^{3}\right)^{\mathrm{II}}$ & $2.3 \pm 0.2^{\mathrm{b}}$ & $2.7 \pm 0.4^{\mathrm{ab}}$ & $2.8 \pm 0.3^{\mathrm{a}}$ & $2.7 \pm 0.3^{\mathrm{ab}}$ & $2.7 \pm 0.3^{\mathrm{ab}}$ \\
$\mathrm{Ht} \%$ & $31.8 \pm 0.8^{\mathrm{c}}$ & $37.5 \pm 2.4^{\mathrm{ab}}$ & $40.7 \pm 1.2^{\mathrm{a}}$ & $35.6 \pm 2.3^{\mathrm{b}}$ & $39.3 \pm 5.1 \mathrm{a}$ \\
$\mathrm{MCV}(\mu 3)^{\mathrm{III}}$ & $137.4 \pm 13$ & $143.4 \pm 27$ & $148.6 \pm 17.9$ & $132.8 \pm 21.7$ & $146.6 \pm 25.9$ \\
$\mathrm{MCH}(\mu \mathrm{g})^{\mathrm{IV}}$ & $41.5 \pm 4.6$ & $37.9 \pm 15.7$ & $45.41 \pm 11.8$ & $37.72 \pm 6.5$ & $37.5 \pm 5.9$ \\
$\mathrm{MCHC}(\%)^{\mathrm{v}}$ & $30.2 \pm 1.7$ & $26.6 \pm 9.6$ & $30.8 \pm 8.2$ & $28.6 \pm 4.0$ & $26.2 \pm 5.4$ \\
\hline
\end{tabular}

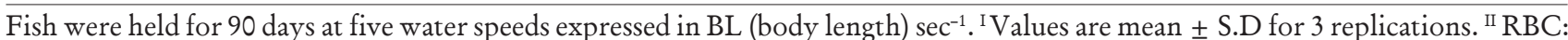

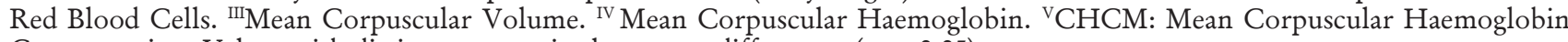
Concentration. Values with distinct superscript letters are differences $(p<0.05)$. 
Table 3 - Proximate body composition (wet weight) of juvenile Brycon amazonicus submitted to sustained swimming.

\begin{tabular}{|c|c|c|c|c|c|c|}
\hline \multirow{2}{*}{$\begin{array}{l}\text { Body } \\
\text { compartment }\end{array}$} & \multirow{2}{*}{ Parameter } & \multicolumn{5}{|c|}{ Water speed } \\
\hline & & 0.0 & 1.0 & 1.5 & 2.0 & 2.5 \\
\hline \multirow{4}{*}{ White muscle } & Moisture & $76.4 \pm 0.1$ & $76.1 \pm 0.2$ & $76.2 \pm 0.3$ & $75.9 \pm 0.2$ & $76.5 \pm 0.3$ \\
\hline & $\mathrm{CP}$ & $20.1 \pm 1.2$ & $20.8 \pm 0.5$ & $20.5 \pm 0.9$ & $20.6 \pm 0.5$ & $20.1 \pm 2.1$ \\
\hline & $\mathrm{EE}$ & $0.79 \pm 1.4$ & $0.81 \pm 1.3$ & $0.92 \pm 0.8$ & $0.93 \pm 0.4$ & $0.80 \pm 0.8$ \\
\hline & CE & 4643.6 & 4755.0 & 4724.6 & 4617.4 & 4613.6 \\
\hline \multirow{4}{*}{ Red muscle } & Moisture & $73.2 \pm 1.3^{a}$ & $71.1 \pm 1.0^{b}$ & $72.7 \pm 1.1^{\mathrm{ab}}$ & $71.4 \pm 1.2^{\mathrm{ab}}$ & $71.4 \pm 1.1^{\mathrm{ab}}$ \\
\hline & $\mathrm{CP}$ & $18.2 \pm 2.2$ & $18.5 \pm 0.7$ & $17.7 \pm 0.4$ & $18.3 \pm 4.3$ & $18.2 \pm 0.5$ \\
\hline & $\mathrm{EE}$ & $4.5 \pm 1.3^{b}$ & $7.8 \pm 2.8^{\mathrm{a}}$ & $6.3 \pm 2.4^{a b}$ & $6.3 \pm 4.6^{\mathrm{ab}}$ & $6.3 \pm 1.7^{\mathrm{ab}}$ \\
\hline & CE & 4863.5 & 5572.6 & 5173.4 & 5575.6 & 5322.4 \\
\hline \multirow{4}{*}{ Liver } & Moisture & $67.3 \pm 1.7^{a b}$ & $65.6 \pm 1.6^{b}$ & $67.6 \pm 1.7^{\mathrm{ab}}$ & $69.6 \pm 4.5^{a}$ & $64.5 \pm 8.4^{\mathrm{ab}}$ \\
\hline & $\mathrm{CP}$ & $14.8 \pm 0.7$ & $15.3 \pm 2.8$ & $14.6 \pm 2.2$ & $13.3 \pm 0.3$ & $14.9 \pm 2.7$ \\
\hline & $\mathrm{EE}$ & $4.9 \pm 1.5^{b}$ & $7.4 \pm 1.5^{a}$ & $4.6 \pm 0.6^{b}$ & $5.7 \pm 3.0^{\mathrm{ab}}$ & $5.6 \pm 2.4^{\mathrm{ab}}$ \\
\hline & CE & 4910.7 & 5253.7 & 5183.6 & 5179.7 & 4965.2 \\
\hline Ventral muscle & $\mathrm{EE}$ & $33.8 \pm 0.6^{d}$ & $40.8 \pm 1.0^{b}$ & $36.3 \pm 0.8^{c}$ & $47.1 \pm 0.9^{a}$ & $41.2 \pm 2.6^{b}$ \\
\hline
\end{tabular}

Fish were held for 90 days at five water speeds expressed in BL (body length) sec ${ }^{-1}$. CP: Crude Protein; EE: Ether Extract; CE: Crude Energy. IValues expressed as \% (mean \pm S.D) for three replications. Distinct superscript letters means differences at $p<0.05$.

behavioral characteristics and body shape suggests that, if submitted to continuous or intermittent exercise, should present enhanced growth performance, which may increase protein contents and reduce lipid deposition in the filets (Arbeláez-Rojas et al., 2002). However, there are not enough data which may elicit evaluating the relevance, for instance, of effects of exercise intensity in body composition of the species. Matrinxa originally inhabits river rapids and otherl well-aerated, flowing water courses, and has a fusiform shape with excellent hidrodynamic performance, well suited for exercise physiology studies (Zaniboni Filho et al., 1988).

As stated, sustained swimming at 1.0 and $1.5 \mathrm{BL} \mathrm{s}^{-1}$ resulted in highest growth rate of matrinxa juveniles compared to other groups. Growth performance of fish swimming at 2.0 and $2.5 \mathrm{BL} \mathrm{s}^{-1}$ were similar to the control. Comparative studies with wild populations of lotic species have shown that these are better swimmers than lentic species (Davison, 1989). Previous studies with matrinxa have shown that fish reared for 72 days at 1.0 $\mathrm{BL} \mathrm{s}{ }^{-1}$ grow faster than non-exercised fish and had improve feed conversion rate (Hackbarth and Moraes, 2006). Some salmonids submitted to sustained swimming at moderate speeds were shown to present better growth performance (Davie et al., 1986; Leon, 1986). The maximum growth rate in this group of species is reached at $1.0 \mathrm{BL} \mathrm{s}^{-}$ ${ }^{1}$; higher speeds reduce growth rate (Hammer, 1994). Juvenile striped bass Morone saxatilis also present the best growth performance at moderate swimming speeds of circa 0.5-1.2 $\mathrm{BL} \mathrm{s}^{-1}$ (Young and Cech, 1994). In addition to the best growth performance, homogeneity of the fish stock is a very important farming characteristic.

Accompanying the homogeneity index (Furuya et al., 1998), weight and growth among fish kept at 1.01.5 $\mathrm{BL} \mathrm{s}^{-1}$ were more uniform than at 2.0 and $2.5 \mathrm{BL} \mathrm{s}^{-1}$
(Table 1). The larger heterogeneity of fish length and growth usually observed in matrinxa more likely results from hierarchy established in the farming system (Jørgensen and Jobling 1993; Jobling et al., 1993; Christiansen et al. 1989), where fish stock from the same species gradually evolve into a dominant (larger size; surface swimmers) and a subordinate (smaller sized; bottom swimmers) class, clearly observed a captive matrinxa school. Exercise seems to reduce this adverse effect. Size homogeneity is also observed in salmonids endured swimming as compared to non-exercised fish (Jobling et al., 1993). In lentic waters some fingerling fish tend to eat more, therefore growing faster and precociously reaching juvenile stage. In addition, factors as individual, genetic differences may contribute for the size heterogeneity.

The assembly of genetic traits results in the development of specimens better suitable for best food conversion, adaptation to the farming environment and resistance to stressing agents. Specimens bearing such set of traits are usually called head-water fish in opposition to the retardatory ones (Jobling et al., 1993; Davison, 1997). In addition to such intrinsic factor, proper fish farming management are essential. The feeding practices and stocking density can affect homogeneity. It has been reported different growth performances, feed conversion, survival rates and size uniformity for matrinxa reared in three stocking densities (Arbeláez-Rojas and Moraes, 2009). High stocking density and inadequate feed allowance will result in higher competition so hampering size uniformity. Hence, larger, dominant and more aggressive fish eat more and hold back the submissive fish (Carter et al., 1992; McCarthy et al., 1992). Sustained swimming can reduce such undesirable effect (Jobling et al., 1993). 
Salmonids submitted to intense water flow find their bearings against the flow forming schools and reducing conflict occurrences (Christiansen and Jobling, 1990). The behavior of matrinxa submitted to continuous swimming was noticeably changed. The fish were tranquil, swimming in schools during the light periods and spreading during the dark. Considering such behavior was accompanied by increased size homogeneity, it is fair to infer that competition was reduced, that is, this behavior more likely resulted in uniform food intake, maximizing growth rate. In addition to directly observed parameters as growth and development, organic factors also changed in matrinxã. The exercise resulted in adaptive responses at hematological level.

Compared to control fish, matrinxa kept at constant swimming showed increased $\mathrm{Ht}, \mathrm{Hb}$ and $\mathrm{RBC}$. Regardless of being discreetly higher among the most exercised fish, these parameters were significantly higher in those submitted to $1.5 \mathrm{BL} \mathrm{s}^{-1}$. The metabolic demand imposed by different swimming speeds should have contributed to this effect. Similar response was observed in $14-\mathrm{cm}$ fingerlings of the species submitted to sustained swimming at $42 \mathrm{~cm} \mathrm{~s}^{-1}$ (Hackbarth and Moraes, 2006), i.e., at 3.0 $\mathrm{BL} \mathrm{s}{ }^{-1}$. Hemoglobin concentration is reportedly higher in exercised matrinxa, so these observations strongly suggest that matrinxa is responsive to exercise concerning hematological profile. Other relevant element to be considered is the fact that matrinxa originally inhabits lotic environments. There is a correlation between red blood cells size and oxygen transport capacity (Lay and Baldwin, 1999). Particularly, there is an inverse correlation between red blood cells size and the fish ability to aerobic swimming. High $\mathrm{Hb}$ concentration and smaller red blood cells volume is observed in the family Carangidae, active swimmers characterized by well developed red muscles fitted to hold sustained swimming. Sedentary species, typical from lentic environments, present low $\mathrm{Hb}$ concentrations associated to large red blood cells. Furthermore, they present a poorly developed red muscle, which are quickly exhausted during burst-swimming (Lay and Baldwin, 1999).

Even though it is known that factors such as sustained swimming can effective alter BC improving productivity, most correlated works focus in nutritional composition of diets, especially in regard to effects of sources and levels of protein, lipid and carbohydrate on BC. Changes in such parameter resulting from sustained swimming depend not only on diet composition but also on exercise intensity and fish size (Rasmussen, 2001; Kiessling et al., 2005). Remarkable changes were observed in the $\mathrm{BC}$ of matrinxa submitted to increasing swimming speeds. Such changes are directly related to metabolism adaptations. Previous work has shown that matrinxa's metabolism is responsive to sustained swimming (Hackbarth and Moraes, 2006). A small increase in protein content was observed in matrinxa enduring 1.0 BL s ${ }^{-1}$ water flow. Such protein deposition resulted from the best feed conversion. Changes in body compo- sition versus exercise seem to be dependent on fish species, feeding, and intensity and duration of the exercise (Davison, 1997). The muscle phenotypic plasticity is very expressive in response to exercise, and the muscle protein delivery is a result of muscle fiber hypertrophy (Totland et al., 1987; Johnston, 1999). Concerning the lipids, its deposition increased and the reduction of water content, either in red muscle or liver of fish submitted to swimming speed of $1.5 \mathrm{BL} \mathrm{s}^{-1}$, are suggestive of anabolic effect resultant from exercise. Similar results were observed in white muscle of brown trout Salmo trutta submitted to sustained swimming at $1.5 \mathrm{BL} \mathrm{s}^{-1}$ (Davison and Goldspink, 1977). At higher speeds, up to $3.0 \mathrm{BL} \mathrm{s}^{-1}$, lipids were consumed as energy fuel in white and red muscles. In Arctic charr Salvelinus alpinus kept under sustained swimming (Christiansen et al., 1989), lipid deposition decreases with increasing body protein. The same pattern of response was observed in matrinxa.

The swimming speeds in which fish should present lower growth rates, lower lipid deposition and higher water content in the body, in comparison to sedentary animals, are more likely those in which high energy levels should be required to sustain them against the water flow (Hernández et al., 2002). However, matrinxa presented an opposite response, since the adaptations observed to the swimming speed were reflected in enhanced body weight and increased lipid stores in the liver, red and ventral muscle, making up for metabolic, energetic demands. Moreover, the crude energy contents increased in the liver, white and red muscle of fish under sustained swimming. In conclusion, juvenile matrinxa grew better and more homogeneously under sustained swimming of 1.0 to $1.5 \mathrm{BL} \mathrm{s}^{-1}$. The species' hematological parameters and $\mathrm{BC}$ were enhanced in response to the metabolic demand imposed by swimming, and these responses are tissue specific, that is, protein deposition and the energy storage, particularly lipids, increased in response to the swimming speeds in the white muscle, ventral muscle and liver. The farming of matrinxã in systems which allow fish to experience sustained swimming may result in enhanced productivity.

\section{Acknowledgements}

To the Conselho Nacional de Desenvolvimento Científico e Tecnológico [CNPq - National Council for Scientific and Technological Development] for sponsoring this work and the colleagues of the Adaptive Biochemistry Laboratory for logistic support.

\section{References}

Arbeláez-Rojas, G.A; Fracalossi, D.M; Fim, J.L. 2002. Body Composition of Tambaqui, Colossoma macropomum, and Matrinxã, Brycon cephalus, When Raised in Intensive (Igarapé Channel) and Semi-Intensive (Pond) Culture Systems. Revista Brasileira de Zootecnia 31: 1059-1069. (in Portugues, with abstract in English).

Arbeláez-Rojas, G.A; Moraes, G. 2009. Sustained swimming and stocking density interaction in the performance and body composition of matrinxã Brycon amazonicus juveniles. Ciência Rural 39: 201-208. (in Portugues, with abstract in English). 
Association of Official Analytical Chemists [AOAC]. 1990. Official Methods of Analysis of AOAC. AOAC, Arlington, VA, USA. 1990. 1298p

Bjornevik, M; Karlsen, O; Johnston, I.A; Kiessling, A. 2003. Effect of sustained exercise on white muscle structure and flesh quality in farmed cod gadus morbua. Aquaculture Research 34: 55-64.

Brandão, F.R; Gomes, L.C; Chagas, E.C; Araújo, D.L; Ferreira, A.L. 2005. Stocking density of matrinxã (Brycon amazonicus) during second growth phase in cages. Pesquisa Agropecuária Brasileira 40: 299-303. (in Portugues, with abstract in English).

Bugeon, J; Lefevre, F; Fauconneau, B. 2003. Fillet texture and muscle structure in brown trout Salmo trutta subjected to longterm exercise. Aquaculture Research 34: 1287-1295.

Christiansen, J.S; Jobling, M. 1990. The behaviour and the relationship between food intake and growth and juvenile Arctic charr, Salvelinus alpinus L., subjected to sustained exercise. Canadian Journal of Zoology 68: 2185-219.

Christiansen, J.S; Ringo, E; Jobling, M. 1989. Effects of Sustained Exercise on Growth and Body Composition of First-Feeding Fry of Arctic Charr, Salvelinus alpinus (L.). Aquaculture 79: 329335.

Collier, H.B. 1944. The standardition of blood haemoglobin determinations. Canadian Medicine Association Journal 50: 550552.

Davie, P.S; wells, R.M; Tetens, V. 1986. Effetcs of sustained swimming on rainbow trout muscle structure, blood oxygen transport, and lactate dehydrogenase isozymes: evidence for increased aerobic capacity of white muscle. Journal of Experimental Zoology 237: 159-171.

Davison, W.; Goldspink, G. 1977. The effect of prolonged exercise on the lateral musculature of the brown trout, Salmo trutta. Journal of Experimental Biology 70: 1-12.

Davison, W. 1997. The effects of exercise training on teleost fish, a review of recent literature. Comparative Biochemistry and Physiology 117: 67-75.

Davison, W. 1989. Training and its effects on teleost fish. Comparative Biochemistry and Physiology 94: 1-10.

Drabkin, D. 1948. The standardization of hemoglobin measurement. American Journal of Medical Science 215: 110-111.

Furuya, W.M; Souza, S.R; Furuya, V.R.B. Hayashi, C.; Ribeiro, R.P. 1998. Pelleted and extruded diets for reversed Nile Tilapia (Oreochromis niloticus L.) males, in finishing phase. Ciência Rural 3: 483-487. (in Portuguese, with abstract in English).

Gomes, L.C.; Urbinati, E.C. 2005. Matrinxã (Brycon amazonicus). p. 149-174. In Baldisserotto, B., Gomes, L.C., ed. Espécies Nativas para Piscicultura no Brasil. Editora UFSM, Santa Maria, RS, Brazil.

Gentzkow, C.J; Masen, J.M. 1942. An accurate method for the determination of blood urea nitrogen by direct nesslerization. Journal of Biological Chemistry 143: 531-544.

Hackbarth, A; Moraes, G. 2006. Biochemical responses of matrinxa Brycon cephalus (Gunther, 1869) after sustained swimming. Aquaculture Research 37: 1070-1078.

Hammer, C. 1994. Effects of endurance swimming on the growth of o-and 1-age group of whiting, Merlangius merlangus, Gadidae. Archives of Fish Marine Research 42: 105-122.

Hernández, M.D; Mendiola, P; Costa, J; Zamora, S. 2002. Effects of intensive exercise on rainbow trout growth, body composition and metabolic responses. Journal of Physiology and Biochemistry 58: 1-8.

Inoue, L.A.K.A; Santos-Neto, C; Moraes, G. 2003. Clove oil as anesthetic for juveniles of matrinxã, Bricon cephalus (Gunther, 1869). Ciência Rural 33: 943-947.

Jobling, M. 2001. Nutrient partitioning and influence of feed composition on body composition. Chap 6, p. 131-145. In. Houlihan, D., ed. Food intake in fish. Blackwell-Science, Oxford, UK.
Jobling, M; Baarvik, B.M; Christiansen, J.S; Jorgensen, E.H. 1993. The effects of prolonged exercise training on growth performance and production parameters in fish. Aquaculture International 1: 95-111.

Johnston, I.A. 1999. Muscle development and growth: potential implications for flesh quality in fish. Aquaculture 177: 99-115.

Johnston, I.A; Moon, T.W. 1980. Exercise training in skeletal muscle of brook trout, Salvelinus fontinalis. Journal of Experimental Biology 87: 177-194.

Kiessling, A; Pickova, J; Eales, J.G; Dosanjh, B; Higgs, D. 2005. Age, ration, and exercise affect the acid profile of Chinook salmon, Oncorbrynchus tshawyscha muscle differently. Aquaculture 243: 345-356.

Lay, P.A; Baldwin, J. 1999. What determines the size of teleost erythrocytes? Correlations with transport and nuclear volume. Fish Physiology and Biochemistry 20: 31-35.

Leon, K.A.1986. Effects exercise on feed consumption, growth, food conversion, and stamina of brook trout. Progressive in Fish Culture 48: 43-46.

Lima, A.O; Soares, J.B; Greco, J.B; Galizzi, J; Cançado, J. 1969. Clinical Application of Laboratory Techniques. 4.ed. Guanabara Koogan, Rio de Janeiro, RJ, Brazil. 653p. (in Portuguese).

Rasmussen, R.S. 2001. Quality of farmed salmonids with emphasis on proximate composition, yield and sensory characteristics. Aquaculture Research 32: 767-786.

Rocha, Y.R; Aguiar, J.P.L; Marinho, H.A. Shrimpton, R. 1982. Nutritional quality of some Amazonian fishes. Acta Amazônica 12: 787-794. (in Portuguese, with abstract in English).

Saint-Paul, U. 1984. Investigations on the seasonal changes in the chemical composition of liver and condition from a neotropical characoid fish, Colossoma maropomum (Serrasalmidadae). Amazônia 9: 147-158.

Scorvo Filho, J.D; Marques, L. 1998. An x-Ray São Paulo state fish culture: costs and revenues of different of production systems for the 96/97 production cycle. Panorama da Aquicultura 8:1015. (in Portuguese)

Shearer, K.D. 1994. Factors affecting the proximal composition of cultured fishes with emphasis on salmonids. Aquaculture 119: 63-88.

Sokal, R.R; Rohlf, F.J. 1980. Introducción a la Bioestadística. Reverte, Murcia, España. 360p.

Totland, G.K; Kryvi, H; Jodestol, K.A; Christiansen, E.N; Tangeras, A; Slinde, E. 1987. Growth and composition of the swimming muscle of adult atlantic salmon, Salmo salar during long-term sustained swimming. Aquaculture 66: 299-313.

Weatherley, A.H; Gill, H.S. 1983. Protein, lipid, water and caloric contents of immature rainbow trout, Salmo gairdneri Richardson, growing at different rates. Journal of Fish Biology 23: 653-673.

Yogata, H; Oku, H. 2000. The effects of swimming exercise on growth and whole-body protein and fat contents of fed and unfed fingerling yellowtail. Fish Science 66: 1100-1105.

Young, P.S; Cech, J.R. 1994. Optimum exercise conditioning velocity for growth, muscular development, and swimming performance in young-of-the-year striped bass, (Morone saxatilis). Canadian Journal of Fisheries and Aquatic Sciences 51: 15191527.

Zaniboni Filho, E.; Carvalho, J.L.; Villacorta-Correa, M.A.; Resende, E.K. 1988. Caracterização morfológica do matrinxã Brycon cephalus (Günther, 1869) (Teleostei: Characidae). Revista Brasileira de Biologia 48: 41-50.

Received April 22, 2009

Accepted November 18, 2009 